\section{Sponges to wipe away pain}

\section{J. Mann}

IT is claimed that only 10 per cent of rainforest plants have been screened for drug activity, yet these have yielded numerous anticancer, antiviral and antiinflammatory agents. How much greater must be the potential of marine organisms, which are far more diverse. The first comprehensive review of marine natural products did not appear until $1973^{1}$, and since then there has been a veritable flood of papers reporting the identification of novel natural products, many with both weird structures and intriguing biological activity. Elucidation of the mechanisms of action of these compounds is very preliminary, but a paper by Faulkner and co-workers ${ }^{2}$ on the sponge metabolites manoalide, luffariellolide and scalaradial, provides a good example of the exciting results that are beginning to emerge.

Manoalide (compound 1, Fig. 1) and luffariellolide (2) are produced by sponges of the Luffariella family, and scalaradial (3) by the sponge Cacospongia mollior. All are potent antiinflammatory agents ${ }^{3}$, apparently working through inhibition of phospholipase $\mathrm{A}_{2}$ activity ${ }^{4}$. This ubiquitous enzyme catalyses the hydrolysis of the ester in the $s n-2$ position of phospholipids, and is implicated in the intracellular release of arachidonic acid with subsequent formation of prostaglandins and leukotrienes via the arachidonic-acid cascade ${ }^{5}$.

The prostaglandins are well-known mediators of pain and inflammation, and the leukotrienes are implicated in various immune reactions and in anaphylaxis. Although many experimental drugs are now available that interfere with the arachidonic-acid cascade, few control activation of phospholipase $\mathrm{A}_{2}$.
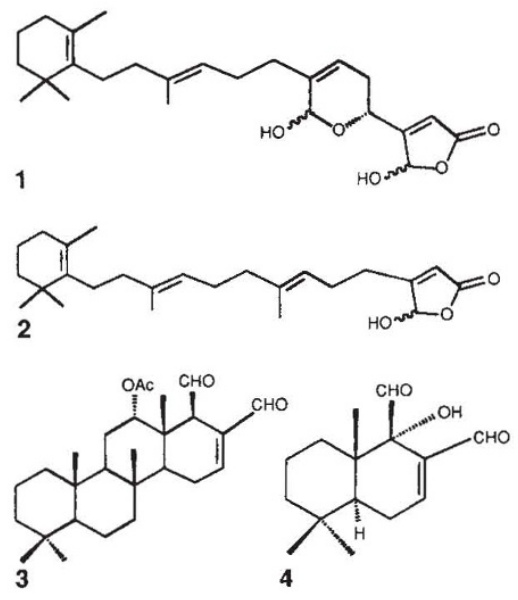

FIG. 1 The metabolites examined by Faulkner and colleagues - $\mathbf{1}$, manoalide, 2, luffariellolide, and $\mathbf{3}$, scalaradial - and 4, warburganal, an insect antifeedant ${ }^{8}$.

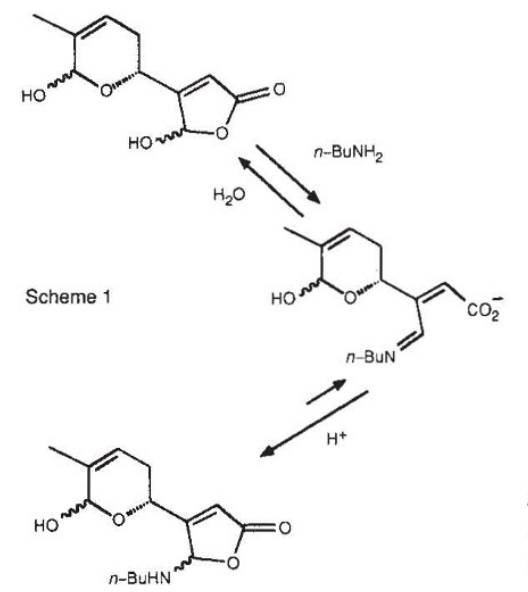
nucleophiles (Nucl) to form the pyrrole 5 .
So the work with the marine natural products is clearly of considerable interest.

All three structures possess either latent aldehyde groups, $\mathrm{CH}=\mathrm{O}$, (the lactols, C-OH, of 1 and 2) or actual aldehyde groups as in 3, and Faulkner et al. demonstrate that these react with one or more lysine residues of phospholipase $\mathrm{A}_{2}$ to form Schiff-base (imine) linkages.

other model reactions tried by Cimino et $a l^{7}$. Given the similarity in structure between scalaradial and other biologically interesting natural products, such as the insect antifeedant warburganal ${ }^{8}(4)$, further chemical and biological experiments are awaited with interest.

For the present, two obvious questions may be posed: can this knowledge be put to any use, and why do sponges produce anti-inflammatory compounds? It is unlikely that these sponge metabolites will ever find their way into the clinic, but this new understanding of their modes of action may stimulate the design and
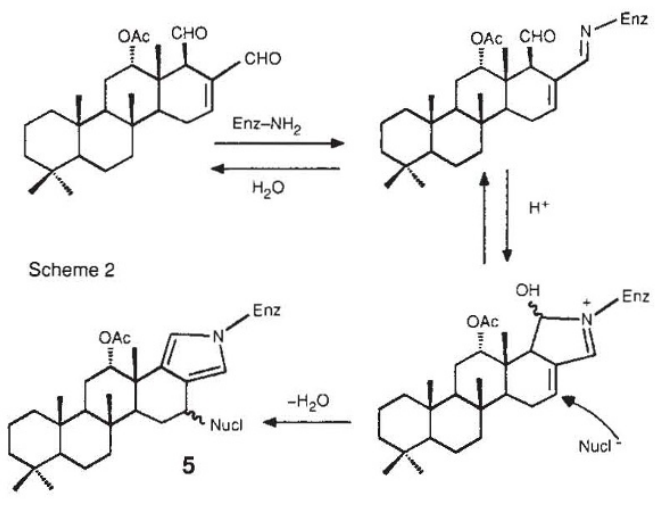

FIG. 2 Phospholipase $A_{2}$ inactivation mechanisms. Scheme 1 , the model compound reacts with the lysine-analogue $n$-butylamine $\left(n-\mathrm{BuNH}_{2}=\mathrm{CH}_{3}-\mathrm{CH}_{2}-\mathrm{CH}_{2}-\mathrm{CH}_{2}-\mathrm{NH}_{2}\right)$ to form a Schiff base. Scheme 2, scalaradial reacts with phospholipase $A_{2}\left(E n z-N_{2}\right)$ in the presence of

Initially they worked with simple analogues of the natural products and reacted these with simple aliphatic amines (Fig. 2, scheme 1). The studies showed that Schiff-base formation is the preferred pathway. But would the enzyme studies reveal the same mode?

In the event, incubation of all three compounds with bee-venom phospholipase $A_{2}$ led to inhibition of the enzyme, but this inhibition could be reversed or prevented if the enzyme was treated with hydroxylamine $\left(\mathrm{H}_{2} \mathrm{NOH}\right)$ at the appropriate time. This is reminiscent of work carried out with rhodopsin ${ }^{6}$. In the retina, retinal is covalently bound to the protein opsin via a Schiff base formed through reaction of a lysine residue and the aldehyde of retinal. In the presence of hydroxylamine (and following exposure to light), an exchange reaction occurs with the formation of retinal oxime (retinal-NOH) and regeneration of the free lysine residue of the opsin.

Faulkner et al. also investigated the progress of inhibition of the enzyme, and reveal that inhibition of phospholipase $A_{2}$ by scalaradial could be reversed by hydroxylamine in the early stages only, and suggest an irreversible inhibition via formation of the pyrrole (5) (Fig. 2, scheme 2). This is in agreement with synthesis of simpler structural analogues with elevated anti-inflammatory activity. Faulkner et al. also suggest that the reversibility of the binding to phospholipase $A_{2}$ may provide a novel means for the purification of the enzyme, through the use of affinity chromatography involving these natural products.

Finally, what of their utility to the sponges? They may simply be distasteful to predators, but it is interesting to speculate that they may bind to specific enzymes in the predator, and interfere with lipid metabolism or with some other vital part of intracellular metabolism.

J. Mann is in the Department of Chemistry, University of Reading, PO Box 224. Whiteknights, Reading RG6 $2 A D$, UK.

1. Scheuer, P. J. Chemistry of Marine Natural Products (Academic, New York, 1973).

2. Potts, B. C. M., Faulkner, D. J., de Carvalho, M. S. \& Jacobs, R. S. J. Am. chem. Soc. 114, 5093-5100 (1992).

3. Jacobs, R. S., Culver, P., Langdon, R., O'Brien, T. \& White, S. Tetrahedron 41, 981-984 (1985).

4. Glaser, K. B., Vedvick, T. S. \& Jacobs, R. S. Biochem. Pharmacol. 37, 3639-3646 (1988).

5. Flower, R. J. \& Blackwell, G. J. Biochem. Pharmacol. 25 285-291 (1976).

6. Akhtar, M., Blosse, P. T. \& Dewhurst, P.B. Biochem. J. 110, 693-702 (1968)

7. Cimino, G., Sodano, G. \& Spinella, A. Tetrahedron 43, 5401-5410 (1987).

8. Kubo, I. et al. J. C. S. Chem. Commun. 1013-1014 (1976). 